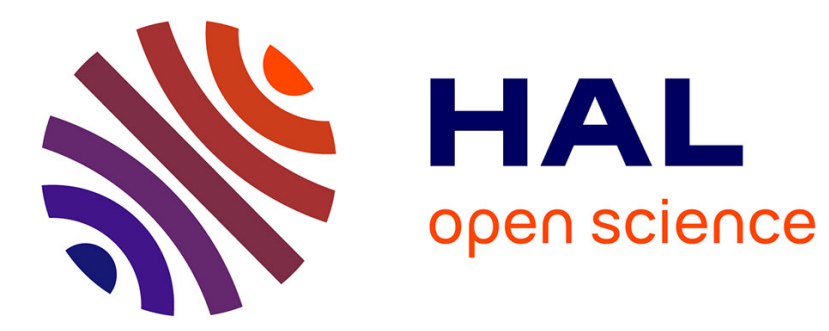

\title{
Use of an ejector for phenol containing water treatment by ozonation
}

Olivier Chedeville, Marie Debacq, Mauro Ferrante Almanza, Catherine Porte

\section{To cite this version:}

Olivier Chedeville, Marie Debacq, Mauro Ferrante Almanza, Catherine Porte. Use of an ejector for phenol containing water treatment by ozonation. Separation and Purification Technology, 2007, 57 (2), pp.201-208. 10.1016/j.seppur.2007.04.004 . hal-00984185

\section{HAL Id: hal-00984185 \\ https://hal.science/hal-00984185}

Submitted on 14 Apr 2017

HAL is a multi-disciplinary open access archive for the deposit and dissemination of scientific research documents, whether they are published or not. The documents may come from teaching and research institutions in France or abroad, or from public or private research centers.
L'archive ouverte pluridisciplinaire HAL, est destinée au dépôt et à la diffusion de documents scientifiques de niveau recherche, publiés ou non, émanant des établissements d'enseignement et de recherche français ou étrangers, des laboratoires publics ou privés.

\section{(ㅇ)(1) $\$$}

Distributed under a Creative Commons Attribution - NonCommercial - NoDerivatives| 4.0 
USE OF AN EJECTOR FOR PHENOL CONTAINING WATER TREATMENT BY

OZONATION

\author{
CHEDEVILLE Olivier ${ }^{\mathrm{a}}$, DEBACQ Marie ${ }^{\mathrm{a} *}$, FERRANTE ALMANZA Mauro ${ }^{\mathrm{a}}$, \\ PORTE Catherine ${ }^{\mathrm{a}}$

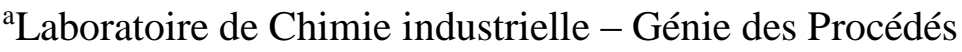 \\ du Conservatoire National des Arts et Métiers \\ Équipe EA21
}

case 302, 2 rue Conté 75003 Paris, France

\begin{abstract}
Mass transfer of ozone in aqueous phase is a major aspect of ozonation and advanced oxidation processes. The aim of this study is to compare the performances of an ejector with those of a more traditional gas/liquid contactor: a bubble column. The hydrodynamic study showed that the volumetric mass transfer coefficient of the ejector $\left(K_{L} a=7.210^{-2}\right.$ to $\left.1.3510^{-1} \mathrm{~s}^{-1}\right)$ was greater than that of the bubble column's $\left(K_{L} a=1.510^{-2}\right.$ to $\left.2.810^{-2} \mathrm{~s}^{-1}\right)$. Very important differences in the values of the residence time and gas retention rate were also observed. A study of phenol degradation was performed. Due to its specifications the ejector is very efficient when the kinetics of reaction is fast (diffusion controlled regime). In both semi batch and open circuits, the phenol was quickly eliminated and the ozone transfer was very high (up to $98 \%$ ). It is to be noted that these results were obtained for a processing time of approximately one second.
\end{abstract}

${ }^{*}$ corresponding author : olivier.chedeville@ cnam.fr 
Key words: treatment process, oxidation, gas/liquid contactor, ozone, mass transfer

\section{Introduction}

An increasingly strict legislation leads industrialists to improve the treatment of their wastewaters by optimizing the existing techniques or by using new processes. Ozonation and advanced oxidation processes are efficient treatment methods allowing the degradation of a great number of organic compounds.

Ozonation consists in molecular ozone acting directly on the nucleophilic sites and unsaturated bonds of the organic compounds. Ozone is one of the strongest oxidants technically applied [1]. Its action is selective, and the kinetics of reaction depends on the nature of the organic compounds [2-4]. For dissociating organic compounds, second order rate constants vary from $10^{-1}$ to $10^{9} \mathrm{~L} \mathrm{~mol}^{-1} \mathrm{~s}^{-1}$ according to the degree of dissociation of the species [5]. Advanced oxidation processes $\left(\mathrm{O}_{3} / \mathrm{H}_{2} \mathrm{O}_{2}, \mathrm{O}_{3} / \mathrm{UV}\right)$ make use of the indirect action of ozone. They are based on the generation of hydroxyl radicals $\mathrm{HO}^{\bullet}$ that are much more reactive and less selective than ozone. Moreover, the kinetics of the reactions are faster: according to compounds, kinetic constants vary from $10^{6} \mathrm{M}^{-1} \mathrm{~s}^{-1}$ to $10^{10} \mathrm{M}^{-1} \mathrm{~s}^{-1}[6,7]$. Due to the fast kinetics of the reactions, the treatment processes using these techniques of oxidation are often limited by the mass transfer of ozone into water [8]. In the present study, two gas/liquid contactors were used: an ejector and a bubble column.

An ejector is a gas/liquid contactor with interesting performances but still little used in industry. It ensures an intimate contact between the two phases and allows a very fast transfer of the ozone into the water. This kind of contactor is based on the conversion of the potential energy of a fluid into kinetic energy (here, the fluid is the liquid to be treated). This transformation is accompanied by a depression used to draw up a second 
fluid (here the oxidizing gas) and create an intimate contact between the two fluids. According to flow rates of the fluids, the contact is more or less intense [9]. The bubble column is a more traditional contactor. A porous diffuser was used to introduce the gas at the bottom of the column, for a counter-current flow. The size of the bubbles depends on the type of diffuser used and the properties of the liquid [10]

Phenol and its derivatives (cresol, xylenol) are compounds largely used in textile, petrochemical and agrochemical industries. Phenol stands out by its organoleptic and bactericidal properties, making it difficult to treat by traditional ways. The decomposition of this compound by ozone has already been studied. The kinetics of the reaction between ozone and phenol is fast: according to Hoigné and Bader [5], the rate of phenol degradation observes a pseudo-first order kinetics with regard to phenol concentration, and the kinetic constant varies from $1.310^{3} \mathrm{M}^{-1} \mathrm{~s}^{-1}$ to $10^{9} \mathrm{M}^{-1} \mathrm{~s}^{-1}$ according to the $p H$, the deprotonated shape of phenol $(p K a=9.9)$ being much more reactive. Esplugas and al. [7] compared different processes of oxidation for phenol degradation; the latter was not always complete (between $56 \%$ and $100 \%$ of pollutant abatement) in spite of relatively important durations of treatment (30 to $80 \mathrm{~min}$ ). It appeared that such parameters as $p H$ or reagents concentration have an important impact on the treatment efficiency.

The objective of this study was to compare the performances of the two gas/liquid contactors. Initially, a hydrodynamic study was performed to estimate the volumetric mass transfer coefficient $K_{L} a$ and to observe its variations according to the operational parameters. Then, a phenol solution was treated in order to observe the efficiency of the treatment method in terms of pollutant abatement and mass transfer. 


\section{Materials and methods}

\subsection{Gas circuit}

Ozone was produced from pure oxygen in a LABO LOX ozonator, provided by the Trailigaz company. This type of apparatus guarantees an average ozone production of $16 \mathrm{~g} \mathrm{~h}^{-1}$ for a concentration of $5 \%$ in weight. The gas flow rate $G$ could be regulated from 0.1 to $0.8 \mathrm{Nm}^{3} \mathrm{~h}^{-1}$. The unconverted ozone was led to a thermal destructor. For the two installations, the gas circuit were made of Teflon. The valves, flowmeters and nonreturn valves, provided by company EM-Technik, were made of PFA.

\subsection{Description of oxidation pilots}

\subsubsection{Case of the ejector}

The polluted liquid contained in a tank, whose volume was $V_{T, E}=310^{-2} \mathrm{~m}^{3}$ (figure 1), was first led to the heat exchanger, then to the ejector (figure 2). The temperature $T$ of the liquid could be held at between $20^{\circ} \mathrm{C}$ and $35^{\circ} \mathrm{C}$. The liquid flow rate $L$ could be controlled between 0.5 and $1 \mathrm{~m}^{3} \mathrm{~h}^{-1}$. A phenomenon of aspiration of the ozone occurred within the ejector. The two phases, intensely mixed, were then led into the mixture tube (height: $1.04 \mathrm{~m}$; diameter: $210^{-2} \mathrm{~m}$ ), allowing a return of the liquid in the tank. The latter was surmounted by a cyclone used to separate the droplets of water from the gas. This gas was led to the ozone analyzer and to the thermal destructor. With an open circuit set up, the liquid was initially contained in another tank.

\subsubsection{The bubble column}

The bubble column (figure 3) had a cylindrical body (length: $1.4 \mathrm{~m}$; diameter: $0.05 \mathrm{~m}$ ) and a spherical head. The column could contain a volume of liquid of $V_{T, C}=2.510^{-3} \mathrm{~m}^{3}$. A peristaltic pump ensured the circulation of the liquid, introduced at the head of the 
column. A maximum liquid flow rate of $0.16 \mathrm{~m}^{3} \mathrm{~h}^{-1}$ could be obtained. The porous diffuser (diameter of the pores ranging between 41 and $100 \mu \mathrm{m}$ ) was placed at the bottom of the column. The gas could be introduced at a maximum flow rate of $0.2 \mathrm{Nm}^{3} \mathrm{~h}^{-1}$. The unconverted ozone was recovered at the head of the column and was led to the thermal destructor.

\subsection{Hydrodynamic calculations}

\subsubsection{Volumetric mass transfer coefficient $K_{L} a$}

The volumetric mass transfer coefficient $K_{L} a$ is a key parameter for the description of a gas/liquid contactor. The mass transfer coefficient $K_{L}\left(\mathrm{~m} \mathrm{~s}^{-1}\right)$ is a function of the physicochemical properties of the liquid, the bubbles size and the hydrodynamic conditions [11]. The specific area $a\left(\mathrm{~m}^{2} \mathrm{~m}^{-3}\right)$ is the ratio of interfacial area and the volume of the reactor. The latter parameter can be obtained by several methods (chemical or photographic methods). It is a function of the size of the bubbles and their number [10].

According to the model suggested by Gao [12], decomposition of ozone is supposed to be proportional to the concentration of the ozone dissolved in water. The proportionality factor is the constant of decomposition $k_{D}\left(\mathrm{~s}^{-1}\right)$.

It is assumed that the dissolved ozone concentration in the contactors is uniform. This is an approximation in the case of the bubble column, in which the ozone dissolved concentration probably changes along the height, but not for the ejector in which agitation is very strong and contact time very short (see 3.1). According to the diffusional double film theory, the mass balance of ozone in the liquid phase is:

$\phi=V_{C} \cdot K_{L} a \cdot\left(\left[O_{3}\right]^{e q}-\left[O_{3}\right]^{0}\right)-V_{T} \cdot k_{D} \cdot\left[O_{3}\right]^{0}$ 
with $\phi$ : the molar flow of ozone in the liquid phase $\left(\mathrm{mol} \mathrm{s}^{-1}\right), V_{C}$ : the volume of the gas/liquid contactor $\left(\mathrm{m}^{3}\right), V_{T}$ : the volume of liquid $\left(\mathrm{m}^{3}\right), K_{L} a$ : the volumetric mass transfer coefficient of the gas/liquid contactor $\left(\mathrm{s}^{-1}\right), k_{D}$ : the decomposition constant of ozone $\left(\mathrm{s}^{-1}\right),\left[\mathrm{O}_{3}\right]^{e q}$ : dissolved ozone concentration in equilibrium with the partial pressure of ozone in the gas phase $\left(\mathrm{mol} \mathrm{m}^{-3}\right),\left[\mathrm{O}_{3}\right]^{0}$ : dissolved ozone concentration in the bulk liquid $\left(\mathrm{mol} \mathrm{m}^{-3}\right)$.

In the case of the ejector $V_{C}$ corresponds to the volume of the mixing tube $\left(V_{C}=3.310^{-4} \mathrm{~m}^{3}\right)$. In the case of the bubble column, $V_{C}$ is supposed to be identical to the volume of liquid $V_{T, C}$.

A method in two stages was used to determine the values of the two coefficients.

\subsubsection{Stage 1: steady state}

After the ozonation started, the dissolved ozone concentration did not vary any more: the steady state (SS) was obtained: $\phi=0$; then, according to (1):

$k_{D}=k^{\prime} \frac{V c}{V_{T}} K_{L} a$, with $k^{\prime}=\frac{\left[O_{3}\right]_{S S}{ }^{e q}-\left[O_{3}\right]_{S S}{ }^{0}}{\left[O_{3}\right]_{S S}{ }^{0}}$

The value of $\left[\mathrm{O}_{3}\right]_{s S^{e q}}$ was estimated using Henry's law [13]. At $20^{\circ} \mathrm{C}$, $\left[\mathrm{O}_{3}\right]_{\mathrm{Ss}} \mathrm{eq}^{\mathrm{eq}}=0,22 \mathrm{~g} \mathrm{~m}^{-3}$ per $\mathrm{g} \mathrm{Nm}^{-3}$ in the gas phase.

\subsubsection{Stage 2: stopping ozonation}

Ozone production was stopped once steady state was reached. The gas introduced did not contain ozone: $\left[\mathrm{O}_{3}\right]^{e q}=0$. Then, according to (1) and (2):

$$
\frac{d\left[O_{3}\right]^{0}}{\left[O_{3}\right]^{0}}=-\left(k^{\prime}+1\right) \cdot \frac{V_{C}}{V_{T}} \cdot K_{L} a \cdot d t
$$

The term $-\left(k^{\prime}+1\right) \cdot \frac{V_{C}}{V_{T}} \cdot K_{L} a$ is the slope, $\alpha$, of $\ln \left(\left[O_{3}\right]^{0}\right)=f(t)$.

$k^{\prime}$ having been previously estimated, $k_{D}$ and $K_{L} a$ could be calculated. 


\subsubsection{The Hatta number}

The Hatta number is a very important criterion giving information on the competition between the kinetics of the reaction and the diffusion inside the liquid film (table 1). It indicates where the chemical reaction takes place (in the bulk liquid or in the film) and allows to choose the appropriate gas/liquid contactor [10]. In the case of a first order reaction in regards to ozone and compound $A$, the Hatta number is given by [14]:

$$
H a=\frac{\sqrt{k \cdot[A]^{0} \cdot D_{O 3}}}{k_{L}}
$$

with $k$ : the kinetic constant of the reaction between ozone and compound $A\left(\mathrm{M}^{-1} \mathrm{~s}^{-1}\right)$, $\left[A^{0}\right]$ : the concentration of compound $A$ in the bulk liquid $\left(\mathrm{mol}^{-1} \mathrm{~m}^{3}\right), D_{O 3}$ : the diffusivity coefficient of ozone into water $\left(\mathrm{m}^{2} \mathrm{~s}^{-1}\right)$.

The value of $k$ has been estimated by Bader and Hoigné [5] (table 5).

\subsubsection{Mean residence time $t_{r}$}

This parameter allows to determine the average time during which the liquid is in contact with the gas. Working with the bubble column, a sodium chloride solution (100 $\left.\mathrm{g} \mathrm{L} \mathrm{L}^{-1}\right)$ was used as a tracer, by carrying out a pulse injection. The outlet concentration was measured by conductivity.

$t_{r}=\frac{\sum_{t 0}^{t \infty} t \cdot[N a C l] \cdot \Delta t}{\sum_{t 0}^{+\infty}[N a C l] \cdot \Delta t}$

with $[\mathrm{NaCl}]: \mathrm{NaCl}$ outlet concentration measured at $t\left(\mathrm{~mol} \mathrm{~m}^{-3}\right)$. At $t \infty$, $[\mathrm{NaCl}]_{t \infty}=[\mathrm{NaCl}]_{t 0}$

In the case of the ejector, the mean residence time was too short to be measured by this method. Nevertheless, when using a quasi plug flowr reactor, $t_{r}$ is rather close to the transit time $t_{t}$ defined by: 
$t_{t}=\frac{V_{C}}{L+G}$

\subsubsection{Gas retention rate $\varepsilon_{g}$}

$\varepsilon_{g}$ corresponds to the ratio of the gas volume on the total volume. For the bubble column, this parameter was estimated by first measuring the mass of liquid corresponding to $V_{T, C}$, then the mass of liquid in the gas/liquid mixture corresponding to the same volume.

$\varepsilon_{g}=\frac{V_{g}}{V_{g}+V_{L}}$

With $V_{g}$ : gas phase volume of $\left(\mathrm{m}^{3}\right) ; V_{L}$ : liquid phase volume $\left(\mathrm{m}^{3}\right)$

For the ejector, $\varepsilon_{g}$ was determined by Merrouche [9] with a photographic method.

\section{4 phenol degradation calculations}

\subsubsection{Ozone transfer}

The efficiency of the mass transfer is given by the ozone transfer ratio ro3:

$r_{O 3}=\frac{\left(C_{O 3, i}-C_{O 3, o}\right)}{C_{O 3, i}} .100$

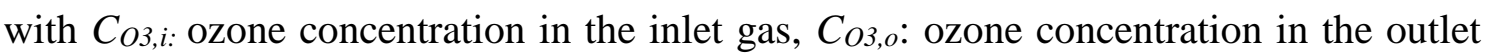
gas $\left(\mathrm{g} \mathrm{Nm}^{-3}\right)$.

\subsubsection{Phenol abatement}

The phenol abatement rate in an open circuit is given by :

$t a=\frac{\left(\left[\text { phenol }_{i}-\left[\text { phenol }_{o}\right) \cdot 100\right.\right.}{[\text { phenol }]_{i}}$

with $[\text { phenol }]_{i}$ : phenol concentration in the inlet liquid $\left(\mathrm{mol} \mathrm{L}^{-1}\right)$, [phenol $]_{o}$ : phenol concentration in the outlet liquid $\left(\mathrm{mol} \mathrm{L}^{-1}\right)$. 
The phenol abatement rate in a semi batch circuit is given by :

$t a=\frac{\left([\text { phenol }]_{t=0}-[\text { phenol }]_{t}\right) \cdot 100}{[\text { phenol }]_{t=0}}$

with $[\text { phenol }]_{t=0}$ : initial phenol concentration $\left(\mathrm{mol} \mathrm{L}^{-1}\right),[\text { phenol }]_{t:}$ phenol concentration at $t\left(\mathrm{~mol} \mathrm{~L}^{-1}\right)$.

\subsubsection{Stoechiometric ratio}

The number of moles of ozone transferred $\left(n_{O 3, t}\right)$ per mole of phenol consumed $\left(n_{p h e n, c)}\right.$ was also determined. In an open circuit, this ratio is given by :

$n_{O 3, t} / n_{\text {phen, }}=\frac{G \cdot C_{O 3, i} \cdot r_{O 3}}{L \cdot[\text { phenol }]_{i} \cdot t a \cdot M_{O 3}}$

with $M_{O 3}$ : molar mass of ozone $\left(\mathrm{g} \mathrm{mol}^{-1}\right)$

\subsection{Analyzes}

\subsubsection{HPLC}

Phenol concentration was monitored by HPLC, C18 lichrospher column. The mobile phase used was a mixture water/acetonitril: $50 / 50$ at a flow rate of $0.7 \mathrm{ml} \mathrm{min}{ }^{-1}$. An UV detector $(210 \mathrm{~nm})$ was used.

\subsubsection{Dissolved ozone}

The ozone dissolved in the aqueous phase was measured by the carmin indigo method: the attack of trisulfonate carmin indigo by $\mathrm{O}_{3}$ in an acid medium leads to a discoloration of the solution, followed by spectrophotometry at $600 \mathrm{~nm}$ (spectrophotometer DR2100, $\mathrm{HACH})$.

\subsubsection{Ozone in gas phase}

The ozone in the gas phase was monitored with a UV spectrophotometer (BMT 961, Messtechnik). This analyzer emits a radiation at $254 \mathrm{~nm}$ (ozone absorption wavelength). 


\section{Results and discussion}

\subsection{Determination of hydrodynamic characteristics}

The $K_{L} a$ and $k_{D}$ coefficients were estimated for different experimental conditions, in order to test the influence of the gas flow rate and liquid flowrate on the transfer capacity of the contactors. Experimental conditions and results are presented in table 2. Carrying out a serie of the same experiment enabled to estimate the experimental uncertainty $\Delta K_{L} a=610^{-3} \mathrm{~s}^{-1}$ and $\Delta k_{D}=610^{-5} \mathrm{~s}^{-1}$.

\subsubsection{Case of the ejector}

All the experiments presented in table 2 were performed at $p H=5.5$, with distilled water and ozone concentration in the inlet gas $C_{O 3, i}=20 \mathrm{~g} \mathrm{Nm}^{-3}$. The results of the experiments 1, 2 and 3, presented in figure 4, showed that the volumetric mass transfer coefficient is an increasing function of $G$ : the value of the volumetric mass transfer coefficient rose from $7.210^{-2} \mathrm{~s}^{-1}$ to $1.3510^{-1} \mathrm{~s}^{-1}$ when $G$ rose from 0.25 to $0.45 \mathrm{Nm}^{3} \mathrm{~h}^{-1}$, these differences being significant with regard to experimental uncertainty. This phenomenon can be explained by a decrease of the transfer resistance in more turbulent conditions and by the increase of the specific area of the contactor. The results of the experiments 3, 4 and 5 showed that liquid flow rate has not influence on the value of $\mathrm{K}_{\mathrm{La}}$ : the differences observed are not significant with regard to experimental uncertainty.

The ozone decomposition coefficient had a similar evolution: it rose from $4.610^{-4} \mathrm{~s}^{-1}$ to $1.1510^{-3} \mathrm{~s}^{-1}$ : this could be explained by a local temperature rise in the ejector when gas flow rate is higher, which lead to a decrease of ozone solubility.

\subsubsection{Case of the bubble column}


The experiments presented in table 2 were performed with tap water $(p H=7.5)$, at $20^{\circ} \mathrm{C}$ and with an ozone concentration in the gas phase of $20 \mathrm{~g} \mathrm{Nm}^{-3}$. The results of experiments $4,5,6$, presented in figure 5, showed that the more important the gas flow rate was (from 0.25 to $0.45 \mathrm{Nm}^{3} \mathrm{~h}^{-1}$ ), the higher the volumetric mass transfer coefficient (from $0.9 \mathrm{~min}^{-1}$ to $1.7 \mathrm{~min}^{-1}$ ) and the ozone decomposition coefficient (from $810^{-2} \mathrm{~min}^{-1}$ to $1510^{-2} \mathrm{~min}^{-1}$ ) were, the variations being significant with regard to the experimental uncertainty. As for the ejector, experiments 8,9 and 10 showed that liquid flow rate has no influence on the value of the volumetric gas transfer.

These results showed that $K_{L} a$ is higher in the ejector. It can be explained by a more important specific area and better mixing conditions.

For the ozone decomposition coefficient, it appeared that $k_{D}$ was higher in the case of the bubble column than in the case of the ejector. This can be explained by the matrix used: tap water was used in the bubble column in order to obtain an homogeneous regime (homogeneous bubble size) for the experimental conditions chosen. This tap water was more basic $p H=7.5$ than distilled water used in the ejector $p H=5.5$. Moreover the tap water contains more competing materials which reacted with ozone. These reactions lead to ozone decomposition and increase of $k_{D}$.

\subsubsection{Discussion}

Table 3 presents the synthesis of the results of the hydrodynamic study of the two gas/liquid contactors, and the experimental fields (values of $G$ and $L$ ) for which these results were obtained. In both cases, the liquid flow rate has an important impact on $t_{r}$ and $\varepsilon_{g}$ values, but not on the volumetric mass transfer coefficient. The gas flow rate has an important influence on $K_{L} a$. This effect can be explained by the rise in the values of the specific area when $G$ increases. It appears that the ejector is more suitable than the 
bubble column in the case of a diffusion-controlled regime $(\mathrm{Ha}>3)$ as the value of its volumetric mass transfer coefficient is higher and its gas retention rate is more important. It is important to notice that the residence time in the mixture tube located under the ejector is very short $(\approx 1 \mathrm{~s})$, whereas it is about $150 \mathrm{~s}$ in the bubble column. The characteristics of the bubble column recommend it for a kinetic-controlled regime. In its study, Gao [12] listed results from litterature obtained for contactors which dimensions are rather close to those used in his reactor (Karman reactor) and to those used in the present study (table 4). The results presented show that the values of the volumetric mass transfer coefficient obtained for the column are in conformity with those estimated by different methods in other studies. It appears that the performances of the ejector are higher than those of the gases/liquid contactors frequently used. Moreover, the experimental results show that it could be interesting to increase $G$ in order to improve the efficiency of the mass transfer when the kinetics of the reaction is fast. However, it is necessary to insure that contact time is sufficiently long.

\subsection{Degradation of phenol}

\subsubsection{Semi batch circuit experiments}

These experiments were performed in order to observe the advisability of using an ejector according to the kinetic regime.

\subsubsection{Experimental conditions}

The kinetics of reaction depends strongly on the $p H$ value [5]. Four experiments, presented in table 5, were performed at different $p H$ levels, involving different Hatta number values ([5]. The other conditions were $L=0.8 \mathrm{~m}^{3} \mathrm{~h}^{-1}, G=0.5 \mathrm{Nm}^{3} \mathrm{~h}^{-1}$, $T=20^{\circ} \mathrm{C},\left[O_{3}\right]_{i}=12 \mathrm{~g} \mathrm{Nm}^{-3},[\text { phenol }]_{\mathrm{t}=0}=610^{-2} \mathrm{~g} \mathrm{~m}^{-3}$. The $p H$ was initially adjusted by addition of $\mathrm{NaOH}$ or $\mathrm{H}_{2} \mathrm{SO}_{4}$. 


\subsubsection{Results and discussion}

The evolutions of the pollutant abatement (figure 6) and ozone mass transfer (figure 7) indicate that phenol was degraded in a first stage. During this degradation, the higher the $p H$ was, the faster the phenol degradation and the higher the ozone transfer ratio were. At $p H=11.3$, phenol was totally degraded in 30 minutes, whereas the treatment time was up to 75 minutes at $p H=2.7$. In a diffusion-controlled regime, the ejector appeared to be very efficient: phenol was quickly degraded and the ozone mass transfer was maximal $\left(r_{O 3}=100 \%\right)$. For the experiments at $p H=11.3$ and $p H=9$, the results were rather close during about 20 minutes: all the ozone introduced was used for the phenol degradation and the reaction was limited by the ozone concentration in the inlet gas. At a lower $p H$, the reaction was slower and the ejector was not the most appropriate gas/liquid contactor.

The second stage corresponds to a by-products oxidation. These by-products (oxalic, glyxalic, maleic, fumaric acids) induce a decrease in $p H$ and were less reactive with the ozone. So, the transfer ratio decreased. Nevertheless, the degradation of these carboxylic acids could be easily realized with a classic biological treatment, and it did not seem worthwhile to continue the treatment after the phenol degradation.

\subsubsection{Open circuit experiments}

In order to compare the performances of the two installations, phenol degradation experiments were carried out in an open circuit.

\subsubsection{Experimental conditions}

For the two couples of experiments (one with the ejector and the other with the bubble column), the experimental conditions were selected according to several criteria: 
- The solutions treated were identical (same pollutant concentration and $p H$, solutions prepared with tap water). So, Hatta number was the same for each couple of experiments.

- The ratio of the quantity of ozone introduced $\left(n_{O 3, i}\right)$ on the quantity of pollutant $\left(n_{p h e n, i}\right)$ was identical.

- All the experiments were carried out at $20^{\circ} \mathrm{C}$.

The other experimental conditions are presented in table 6 . The modification of the kinetic of the reaction by varying the $p H$ enabled to carry out experiments in transition regime $(0.3<H a<3)$ and diffusion controlled regime $(H a>3)$. The $p H$ was initially adjusted by addition of $\mathrm{NaOH}$ or $\mathrm{H}_{2} \mathrm{SO}_{4}$.

\subsubsection{Results and discussion}

At $p H=7.5(H a=1.9)$, the results presented in table 6 show that the bubble column seems to be the most efficient gas/liquid contactor: the phenol abatement rate and the ozone transfer ratio were about $10 \%$ higher than those obtained with the ejector. When the reaction occurred in the bulk liquid and in the film, due its high gas hold-up and residence time, the bubble column is the most efficient.

At $p H=8.5(H a=8.6)$, the results presented in table 6 indicate that the ejector presents better performances: the phenol abatement rate was higher than the one obtained with the bubble column, the quantity of ozone consumed per mole of phenol was smaller and the ozone transfer ratio was higher. These results can be explained by the importance of the contact area between the two phases generated by the ejector. Moreover, an increase in the ozone concentration in the gas phase (technically not feasible here) could allow to obtain a complete and fast phenol elimination with a very efficient mass transfer. 
To conclude, the results showed that in the case of a fast kinetics of reaction, the ejector, which has an important volumetric mass transfer coefficient and gas retention rate, is the more efficient gas/liquid contactor: high levels of ozone mass transfer and pollutant abatement were obtained. In comparison with the results obtained in different studies $([6,7,15,16])$, the use of the ejector allows a significant decrease in ozone consumption: during the experiments carried out at $p H=8.5$ : $r_{O 3}$ was very high $(>98$ $\%)$ and the quantity of ozone used per mole of phenol was small $\left(n_{O 3} / n_{p h e n}=1.9\right)$. Moreover, all these results were obtained for very short contact times (about one second). For a space requirement similar to that of the bubble column, the ejector allowed to treat flow rates approximately 10 times higher in a hundreth of the contact time.

\section{Conclusion}

In a first stage, the hydrodynamic properties of the two contactors were estimated. It appeared that the ejector had higher volumetric mass transfer coefficient and gas retention rate, making it an ideal processing device when the chemical reaction occurs in the bulk liquid. By raising the $p H$, it appeared that the ejector gave better results for the treatment of phenol: for a contact time of about one second between the two phases, a large fraction of ozone introduced was transferred in liquid phase ( $\left.r_{O 3}>98 \%\right)$. So, for diffusion controlled regime (ozonation at sufficiently high $p H$ or advanced oxidation process), the ejector allows a treatment of important flow rate, in a very short time, with a very efficient mass transfer.

\section{Acknowledgment}


The authors wish to thank Caroline Wisniewski (Sanofi Aventis), Marielle Coste and Florencio Martin (Anjou Recherche), and ANVAR for supporting this investigation. 


\section{References}

[1] P. Janknecht, P. A. Wilderer, C. Picard, A. Larbot, Ozone-water contacting by ceramic membranes, Sep. Purif. Technol, Vol. 25 (1-3) (2001), 341-346

[2] U. Von Gunten, Ozonation of drinking water: Part I. Oxidation kinetics and product formation, Wat. Res., Vol. 37 (2003), 1443-1467

[3] J. Hoigné, H. Bader, Rate constants of reaction of ozone with organic and inorganic compounds in water-I, Wat. Res., Vol. 17 (1983), 173-183

[4] J. Beltran-Heredia, J. Torregrosa, J. R. Dominguez, J. A. Peres, Kinetics of the reaction between ozone and phenolic acids present in agro-industrial wastewaters, Wat. Res 35, Vol. 4 (2001), 1077-1085

[5] J. Hoigné, H. Bader, Rate constants of reaction of ozone with organic and inorganic compounds in water-I, Water Res., Vol. 17 (1983), 185-194

[6] C. Canton, S. Esplugas, J. Casado, Mineralization of phenol in aqueous solution by ozonation using iron or copper salts and light, J. Appl. Catal B: environmental, Vol. 43 (2003), 139-149

[7] S. Esplugas, J. Giménez, S. Contreras, E. Pascual, M. Rodrigez, Comparison of different advanced oxidation processes for phenol degradation, Wat. Res., Vol. 36 (2002), 1034-1042

[8] W. Shin, A. Mirmiran, S. Yiakoumi, C. Tsouris, Ozonation using microbubbles formed by electric fields, Sep. Purif. Technol., Vol. 15 (1999), 271-282

[9] S. Merrouche, Ejecteur tubulaire gaz-liquide : comparaison des méthodes chimique et physique pour la détermination des surfaces d'échange. Etude de l'influence des paramètres géométriques, opératoires et physico-chimiques sur les performances, $\mathrm{PhD}$ thesis of université Paris VI et du Conservatoire National des Arts et Métiers, 1998 
[10] M. Roustan, Transferts gaz liquide dans les procédés de traitement des eaux et des effluents gazeux, Tec \& Doc ed, 2003

[11] J. Wu, K. Rudu, J. Spark, 2000, Oxidation of aqueous phenol by ozone and peroxidase, Adv Environ Research, Vol. 4 (2000), 339-346

[12] M-T. Gao, M. Hirata, H. Takanashi, T. Hano, Ozone mass transfer in a new gasliquid contactor-Karman contactor, Sep. Purif. Technol., Vol. 42 (2005), 145-149

[13] W. J. Masschelein, Ozone et ozonation des eaux, Tec \& Doc ed, 1991

[14] J. Rivas, F. Beltran, B. Acedo, O. Gimeno, Two step wastewater treatment : sequential ozonation - aerobic degradation, Ozone Sci. \& Eng., Vol. 22 (2000), 617636

[15] P. Painmanakul, K. Loubière, G. Hébrard, M. Mietton -Peuchot, M. Roustan, Effect of surfactant on liquid-side mass transfer coefficients, Chem. Eng. Sci., Vol. 60 (2005), 6480-6491

[16] N. Takahashi, Ozonation of several organic compounds having low molecular weight under ultraviolet radiation, Ozone Sci. \& Eng., Vol. 12 (1989), 1-18 
FIGURES

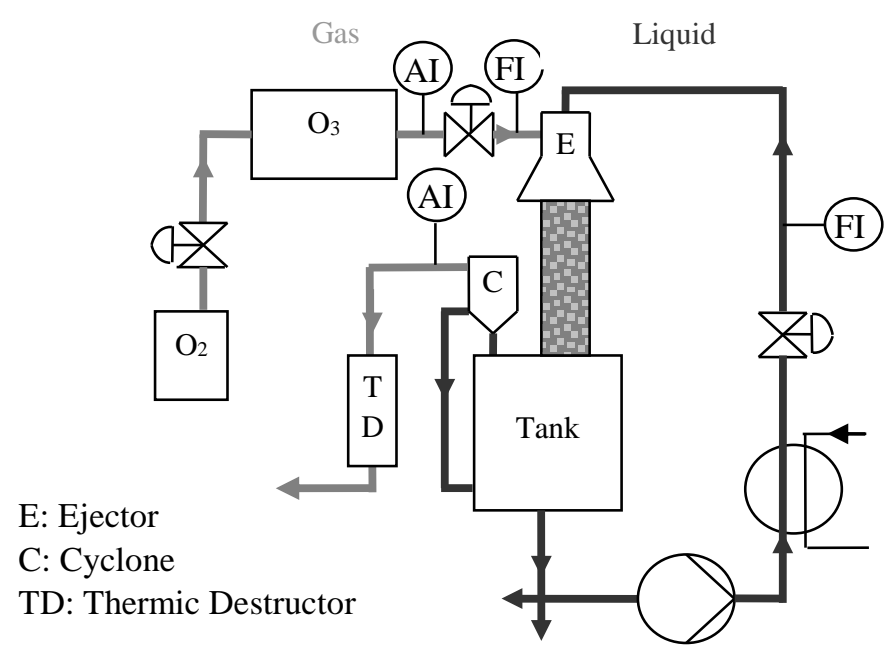

figure 1. schematic of the pilot

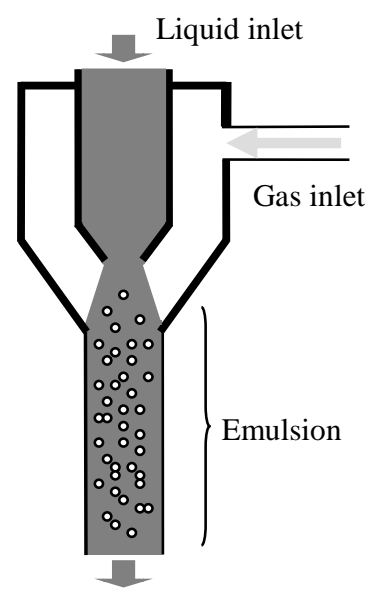

figure 2. ejector 


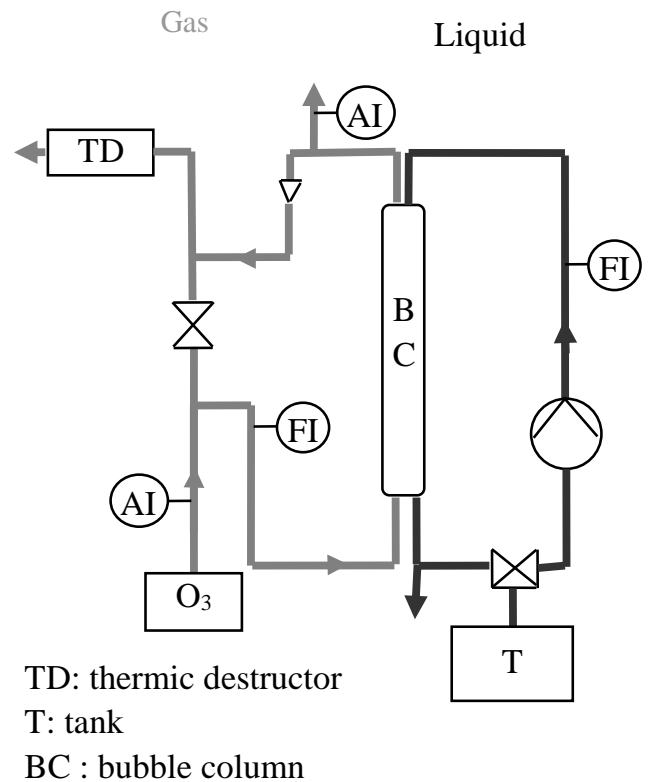

figure 3. schematic of the bubble column

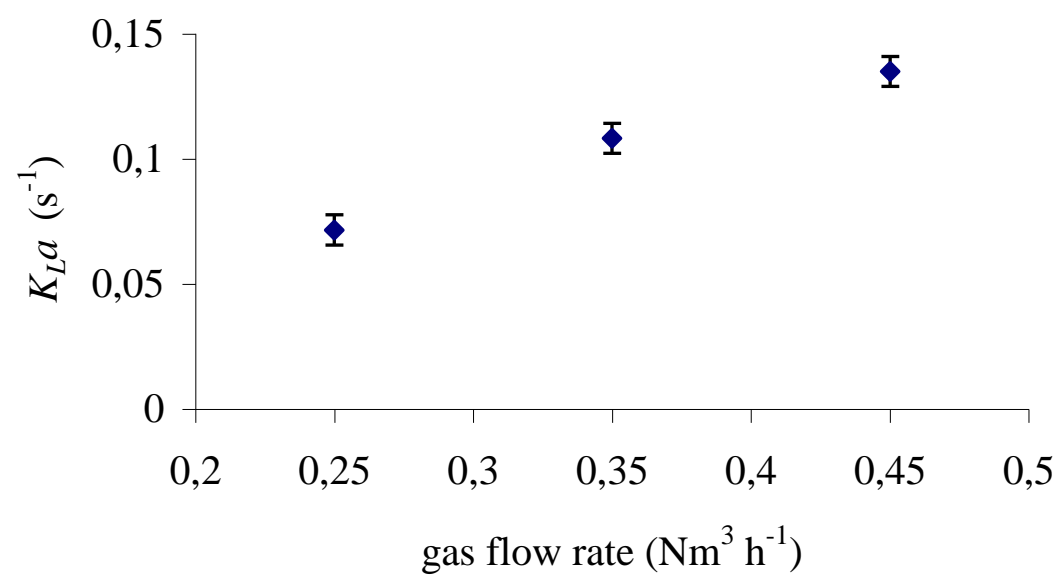

figure 4. influence of $G$ (ejector)

$T=20^{\circ} \mathrm{C}, C_{O 3, i}=20 \mathrm{~g} \mathrm{Nm}^{-3}, p H=5.5, L=0.9 \mathrm{~m}^{3} \mathrm{~h}^{-1}$ 


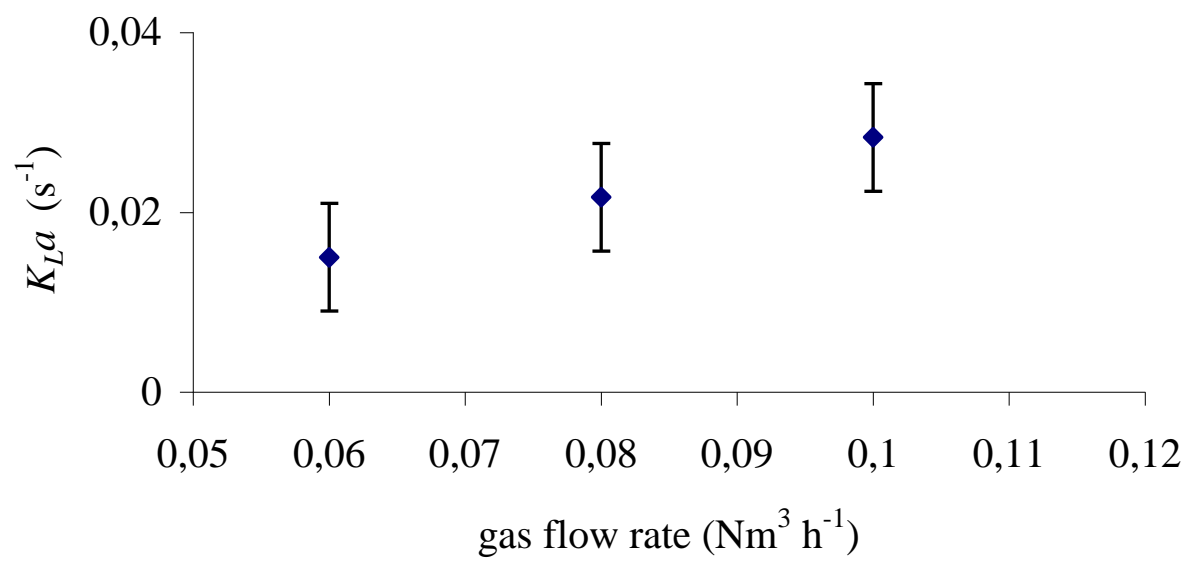

figure 5. influence of $G$ (bubble column)

$T=20^{\circ} \mathrm{C}, C_{O 3, i}=20 \mathrm{~g} \mathrm{Nm}^{-3}, p H=7.5, L=0,12 \mathrm{~m}^{3} \mathrm{~h}^{-1}$

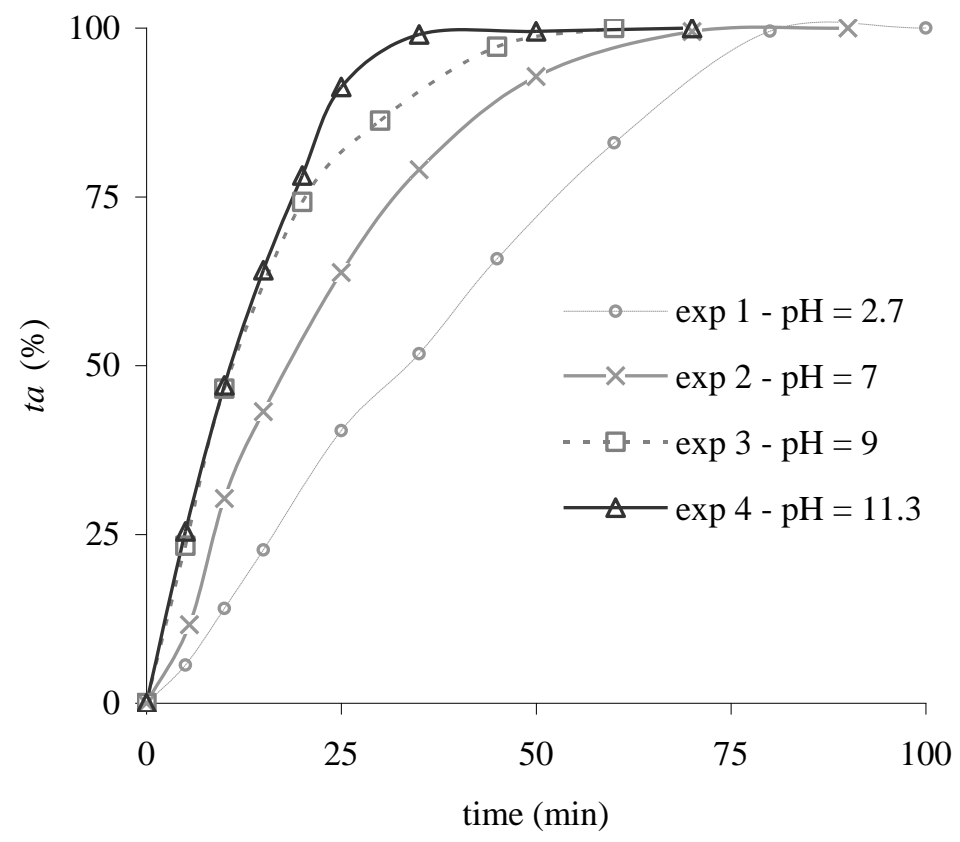

figure 6 : phenol abatement evolution

$L=0.8 \mathrm{~m}^{3} \mathrm{~h}^{-1}, G=0.5 \mathrm{Nm}^{3} \mathrm{~h}^{-1}, T=20^{\circ} \mathrm{C},\left[O_{3}\right]_{i}=12 \mathrm{~g} \mathrm{Nm}^{-3}$, $[\text { phenol }]_{t=0}=610^{-2} \mathrm{~g} \mathrm{~m}^{-3}$

Ejector, semi batch 


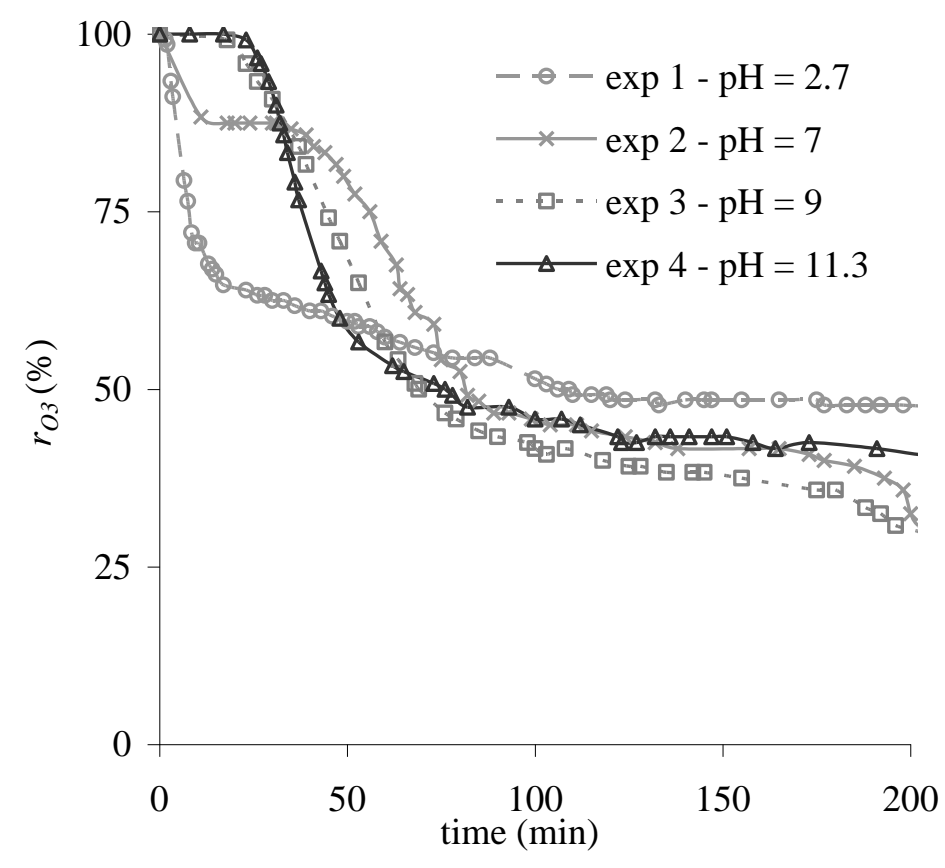

figure $7: r_{O 3}=\mathrm{f}(t)$

$L=0.8 \mathrm{~m}^{3} \mathrm{~h}^{-1}, G=0.5 \mathrm{Nm}^{3} \mathrm{~h}^{-1}, T=20^{\circ} \mathrm{C},\left[O_{3}\right]_{i}=12 \mathrm{~g} \mathrm{Nm}^{-3},[\text { phenol }]_{t=0}=610^{-2} \mathrm{~g} \mathrm{~m}^{-3}$

Ejector, semi batch 


\section{TABLES}

table 1. Hatta number

\begin{tabular}{cccc}
\hline$H a$ & regime & Place of the reaction & G/L contactor characteristic \\
\hline$<0.3$ & kinetic & bulk liquid & liquid volume \\
$0.3-3$ & transition & partially in film & interfacial area and liquid volume \\
$>3$ & diffusion & entirely in film & interfacial area \\
\hline
\end{tabular}

table 2. experimental conditions and results - effect of liquid and gas flow rates

\begin{tabular}{cccccccc}
\hline & Exp. & $\begin{array}{c}L \\
\left(\mathrm{~m}^{3} \mathrm{~h}^{-1}\right)\end{array}$ & $\begin{array}{c}G \\
\left(\mathrm{Nm}^{3} \mathrm{~h}^{-1}\right)\end{array}$ & $k$ & $\begin{array}{c}\text { slope } \alpha \\
\left(10^{-3} \mathrm{~s}^{-1}\right)\end{array}$ & $\begin{array}{c}k_{D} \\
\left(10^{-4} \mathrm{~s}^{-1}\right)\end{array}$ & $\begin{array}{c}K_{L} a \\
\left(10^{-2} \mathrm{~s}^{-1}\right)\end{array}$ \\
\hline \multirow{6}{*}{ Ejector } & 1 & 0.9 & 0.25 & 0.59 & -1.23 & 4.6 & 7.2 \\
& 2 & 0.9 & 0.35 & 0.77 & -2.06 & 9 & 11 \\
& 4 & 0.9 & 0.45 & 0.079 & -1.58 & 11.5 & 13.5 \\
& 5 & 0.8 & 0.45 & 0.201 & -1.75 & 10 & 13.2 \\
& 1.0 & 0.45 & 0.113 & -1.75 & 11.6 & 14.2 \\
\hline \multirow{3}{*}{ Bubble } & 7 & 0.12 & 0.06 & 0.085 & -16.7 & 13 & 1.5 \\
& 8 & 0.12 & 0.1 & 0.086 & -30.8 & 25 & 2.8 \\
& 9 & 0.1 & 0.1 & 0.093 & -28.3 & 23 & 2.6 \\
& 10 & 0.15 & 0.1 & 0.093 & -28.3 & 23 & 2.6 \\
\hline
\end{tabular}

table 3. synthesis of the hydrodynamic study

\begin{tabular}{ccc}
\hline & Bubble column & Ejector \\
\hline$V\left(\mathrm{~m}^{3}\right)$ & $2.510^{-3}$ & $3010^{-3}$ \\
$L\left(\mathrm{~m}^{3} \mathrm{~h}^{-1}\right)$ & $0-0.16$ & $0.5-1$ \\
$G\left(\mathrm{Nm}^{3} \mathrm{~h}^{-1}\right)$ & $0-0.16$ & $0-0.5$ \\
$t_{r}(\mathrm{~s})$ & $60-150$ & $\approx 1$ \\
$\varepsilon_{g}$ & $0.02-0.07$ & $0.2-0.46$ \\
$K_{L} a\left(\mathrm{~s}^{-1}\right)$ & $1.510^{-2}-2.810^{-2}$ & $7.210^{-2}-1.3510^{-1}$ \\
\hline
\end{tabular}


table 4. comparison of the coefficients of transfers of different processes [12]

\begin{tabular}{ccc}
\hline Contactor & Operating conditions & $K_{L} a\left(\mathrm{~s}^{-1}\right)$ \\
\hline bubble column & $C_{O 3, i}=8$ to $60 \mathrm{~g} \mathrm{~m}^{-3}, G=0.3$ to $1.2 \mathrm{Nm}^{3} \mathrm{~h}^{-1}$, & $310^{-3}$ to $210^{-2}$ \\
$(H=5.5 \mathrm{~m})$ & $L=0.1$ to $0.45 \mathrm{~m}^{3} \mathrm{~h}^{-1}$ & \\
fixed bed Column & $C_{O 3, i}=30 \mathrm{~g} \mathrm{~m}^{-3}, G=5$ to $10 \mathrm{Nm}^{3} \mathrm{~h}^{-1}$ & $6.310^{-3}$ to $1.410^{-2}$ \\
electrostatic spray & $C_{O 3, i}=10 \mathrm{~g} \mathrm{~m}^{-3}, G=0.1210^{-1} \mathrm{NL} \mathrm{h}^{-1}$ & $<2.5 .10^{-2}$ \\
Bubble column & $C_{O 3, i}=10 \mathrm{~g} \mathrm{~m}^{-3}, G=0.1210^{-1} \mathrm{NL} \mathrm{h}^{-1}$ & $910^{-3}$ \\
Karman reactor & $C_{O 3, i}=10 \mathrm{~g} \mathrm{~m}^{-3}, G=60{\mathrm{to} 240 \mathrm{NL} \mathrm{h}^{-1}, L=0.66 \text { to }}$ & $8.310^{-3}$ to $2.510^{-3}$ \\
\hline
\end{tabular}

table 5. experimental conditions

\begin{tabular}{cccc}
\hline$p H$ & $\begin{array}{c}k_{\text {O3/phenol }}[5] \\
\left(\mathrm{M}^{-1} \mathrm{~s}^{-1}\right)\end{array}$ & $\mathrm{Ha}$ & regime \\
\hline 2.7 & $10^{3}$ & $710^{-2}$ & kinetic controlled \\
7 & $10^{6}$ & 2 & transition \\
9 & $10^{8}$ & 21 & diffusion controlled \\
11.3 & $>10^{9}$ & $>67$ & diffusion controlled \\
\hline
\end{tabular}

table 6 experimental conditions and results

A : transition regime: $p H=7,5$; $[\text { phenol }]_{i}=10^{-2} \mathrm{~g} \mathrm{~L}^{-1}$;

B : diffusion controlled regime: $p H=8,5$; [phenol $]_{i}=210^{-2} \mathrm{~g} \mathrm{~L}^{-1}$

\begin{tabular}{|c|c|c|c|c|c|c|c|}
\hline & $\begin{array}{c}L \\
\left(\mathrm{~m}^{3} \mathrm{~h}^{-1}\right)\end{array}$ & $\begin{array}{c}G \\
\left(\mathrm{Nm}^{3} \mathrm{~h}^{1}\right)\end{array}$ & $\begin{array}{c}C_{O 3, i} \\
\left(\mathrm{~g} \mathrm{Nm}^{-3}\right)\end{array}$ & $\mathrm{Ha}$ & $\begin{array}{c}t a \\
(\%)\end{array}$ & $\begin{array}{l}r_{O 3} \\
(\%)\end{array}$ & $n_{O 3, t} / n_{\text {phen,c }}$ \\
\hline column & 0.1 & 0.1 & 13 & 1.9 & 85.4 & 93.1 & 2.8 \\
\hline ejector & 0.8 & 0.35 & 30 & 1.9 & 76.2 & 81 & 2.8 \\
\hline column & 0.1 & 0.1 & 13 & 8.6 & 52 & 95 & 2.6 \\
\hline ejector & 0.8 & 0.35 & 30 & 8.6 & 74 & 98 & 1.9 \\
\hline
\end{tabular}

